\title{
Hepatogenic and neurogenic differentiation of bone marrow mesenchymal stem cells from abattoir-derived bovine fetuses
}

Fernando Dueñas ${ }^{1}$, Víctor Becerra', Yennifer Cortes ${ }^{1}$, Sonia Vidal2 ${ }^{2}$ Leonardo Sáenz ${ }^{2}$, Jaime Palomino ${ }^{1}$, Mónica De los Reyes ${ }^{1}$ and Oscar A Peralta ${ }^{1,3^{*}}$

\begin{abstract}
Background: Mesenchymal stem cells (MSC) are multipotent progenitor cells characterized by their ability to both self-renew and differentiate into tissues of mesodermal origin. The plasticity or transdifferentiation potential of MSC is not limited to mesodermal derivatives, since under appropriate cell culture conditions and stimulation by bioactive factors, MSC have also been differentiated into endodermal (hepatocytes) and neuroectodermal (neurons) cells. The potential of MSC for hepatogenic and neurogenic differentiation has been well documented in different animal models; however, few reports are currently available on large animal models. In the present study we sought to characterize the hepatogenic and neurogenic differentiation and multipotent potential of bovine MSC (bMSC) isolated from bone marrow (BM) of abattoir-derived fetuses.
\end{abstract}

Results: Plastic-adherent bMSC isolated from fetal BM maintained a fibroblast-like morphology under monolayer culture conditions. Flow cytometric analysis demonstrated that bMSC populations were positive for MSC markers CD29 and CD73 and pluripotency markers OCT4 and NANOG; whereas, were negative for hematopoietic markers CD34 and CD45. Levels of mRNA of hepatic genes a-fetoprotein (AFP), albumin (ALB), alpha1 antitrypsin (a1AT), connexin 32 (CNX32), tyrosine aminotransferase (TAT) and cytochrome P450 (CYP3A4) were up-regulated in bMSC during a 28-Day period of hepatogenic differentiation. Functional analyses in differentiated bMSC cultures evidenced an increase $(P<0.05)$ in albumin and urea production and glycogen storage. bMSC cultured under neurogenic conditions expressed NESTIN and MAP2 proteins at $24 \mathrm{~h}$ of culture; whereas, at $144 \mathrm{~h}$ also expressed TRKA and PrPC. Levels of MAP2 and TRKA mRNA were up-regulated at the end of the differentiation period. Conversely, bMSC expressed lower levels of NANOG mRNA during both hepatogenic and neurogenic differentiation processes.

Conclusion: The expression patterns of linage-specific markers and the production of functional metabolites support the potential for hepatogenic and neurogenic differentiation of bMSC isolated from BM of abattoir-derived fetuses. The simplicity of isolation and the potential to differentiate into a wide variety of cell lineages lays the foundation for bMSC as an interesting alternative for investigation in MSC biology and eventual applications for regenerative therapy in veterinary medicine.

Keywords: Bovine fetuses, Mesenchymal stem cell, Differentiation potential, Hepatocyte-like cell, Neuron-like cell

\footnotetext{
* Correspondence: operalta@uchile.cl

'Departamento de Fomento de la Producción Animal, Facultad de Ciencias Veterinarias y Pecuarias, Universidad de Chile, Santiago, Chile

${ }^{3}$ Department of Biomedical Sciences and Pathobiology, Virginia-Maryland Regional College of Veterinary Medicine, Virginia Polytechnic Institute and State University, Blacksburg, VA 24061-0442, USA

Full list of author information is available at the end of the article
} 


\section{Background}

Mesenchymal stem cells (MSC) are multipotent progenitor cells characterized by their ability to both self-renew and differentiate into tissues of mesodermal origin (osteoblasts, adipocytes, chondrocytes and myocytes) [1]. Despite several tissues have been explored for the isolation of MSC including adipose, umbilical and placental; animal bone marrow (BM) is the most common source of MSC for clinical and research uses. MSC are directly isolated from bone marrow aspirates based on their ability to adhere to plastic when plated in monolayer culture and thereafter replicate ex vivo to form a phenotypically homogeneous population of cells [2]. Plastic adherence under standard culture conditions is one of the criteria for defining MSC by the International Society for Cellular Therapy (ISCT). Other requirements include trilineage differentiation potential and expression of MSC surface antigens markers CD105 (endoglin), CD73 (ecto-5'-nucleotidase) and CD90 (Thy-1), and lack of expression of hematopoietic markers CD45 (protein tyrosine phosphatase, receptor type, C), CD34 (CD34 molecule) and CD14 (CD14 molecule) [3].

Despite the wide relevance of the bovine experimental model in both in vivo and in vitro experiments, limited information regarding bovine MSC (bMSC) is available. Similarities in organ size and physiology with humans and a longer life span in comparison with traditional laboratory animal models support the use of large animal models for long-term experiments in regenerative medicine $[4,5]$. Development of a bMSC model would be invaluable for testing the efficiency and safety of these cells for future cell therapies and for the creation of human disease models. Moreover, cattle can give advantages for clinical applications of MSC to human and veterinary medicine especially in musculoskeletal disorders [6-8].

Previous studies reported isolation and mesenchymal differentiation of bMSC from calf BM [7,9] and bovine umbilical cord [10,11]. We have reported the isolation and mesenchymal multilineage differentiation of bMSC derived from $\mathrm{BM}$ of abattoir-derived bovine fetuses [12]. Studies performed on human MSC isolated from fetal $\mathrm{BM}$ have shown that these cells possess higher proliferative capacity, trilineage differentiation potential and lower immunogenicity compared to MSC from umbilical cord, adult BM or adipose tissue [13]. Moreover, human fetal MSC isolated from BM had higher proliferative and osteogenic capacity than MSC derived from other ontological and anatomical origins, suggesting that they are superior candidates for bone tissue engineering $[13,14]$. The simplicity of isolation and the potential to differentiate into several cell types lays the foundation for fetal bMSC, as an interesting source for investigation of stem cell biology. Moreover, the development of large animal experimental models including cattle may open alternative strategies for investigating MSC physiology and eventual applications for regenerative therapy in human and veterinary medicine. As an example, recently it has been proposed the potential application of various stem/progenitor cells including mammary stem cells for the repair of post-mastitis structural defects in dairy animals $[15,16]$.

The plasticity or transdifferentiation potential of MSC is not limited to mesenchymal derivatives, since under appropriate cell culture conditions and stimulation by certain exogenous or endogenous bioactive factors, MSC have also been differentiated into endodermal (hepatocytes) and neuroectodermal (neurons) cells $[17,18]$. The potential for hepatogenic differentiation of MSC has been evaluated by measuring the expression of endodermal or hepatocyte markers including $\alpha$-fetoprotein (AFP), albumin (ALB), alpha1 antitrypsin ( $\alpha 1 \mathrm{AT})$, connexin 32 (CNX32), tyrosine aminotransferase (TAT) and cytochrome P450 (CYP3A4) [19]. The functional capacity has also been assessed by determining urea production and glycogen storage [18]. Moreover, a large body of evidence has established the neural differentiation potential of MSC derived from BM. Treatment of BM-MSC with different molecules and growth factors induced rapid morphological changes that are typical of neural cells together with the expression of neural markers such as neuroepithelial stem cell intermediate filament (NESTIN), microtubule associated protein 2 (MAP2), nerve growth factor (NGF), tropomyosin-related kinase $\mathrm{A}$ (TRKA) and cellular prion protein $\left(\operatorname{PrP}^{\mathrm{C}}\right)$ [20-22]. Thus, the potential for isolation and differentiation into hepatocyte- and neuron-like cells, as well as their capacity for transplantation, suggests that MSC represent an attractive therapeutic candidate for treating degenerative diseases.

In the present study, we used abattoir-derived bovine fetuses as an available and plentiful source of BM with the aim to obtain an abundant supply of bMSC for in vitro differentiation experiments. Our main objective was to characterize the hepatogenic and neurogenic differentiation potential of bMSC isolated from abattoirderived bovine fetuses by gene expression and functional analyses.

\section{Results}

Mesenchymal cell surface marker and multipotent profile of BM-bMSC from abattoir-derived fetuses

Fetal bMSC were isolated from BM based on the capacity for plastic attachment under standard culture conditions that included DMEM media supplemented with 10\% FBS. After 5 to 6 days of culture, colonies of fibroblast-like cells were visualized attached to plastic culture flasks. Isolated cells were cultured for several weeks in monolayer and used for differentiation experiments after 4 to 5 passages. Flow cytometric analysis of bMSC demonstrated that higher $(\mathrm{P}<0.05)$ percentage of these cells were positive for MSC markers CD29 (76.3\%) and CD73 (96.8\%) and pluripotency 
markers OCT4 (94.6\%) and NANOG (88.4\%) (Figure 1). In comparison, a higher $(\mathrm{P}<0.05)$ percentage of cells was negative for hematopoietic markers CD34 and CD45 (93.4\% and 95.6\%, respectively).

\section{Gene expression profile in bMSC during hepatogenic differentiation}

Culture of bMSC in monolayer under hepatogenic conditions induced polygonal cell morphology and formation of cell aggregates at Day 28 of culture (Figure 2A). AFP protein was immunodetected in differentiated bMSC at Day 28 of culture (Figure 2B). At this stage, levels of $A F P, A L B$, $\alpha 1 A T, C N X 32, T A T$ mRNA levels were up-regulated $(\mathrm{P}<0.05)$ in differentiated bMSC $(60.6-, 331.4-, 166.8-$, 201.1-, 446.5-fold relative to Day 0, respectively) (Figure 2B). Levels of CYP3A4 mRNA were higher $(\mathrm{P}<0.05)$ in differentiated compared to control bMSC from Day 7 until Day 28 of culture (154.7- and 104.4-fold relative to Day 0 vs. 69and 34-fold in untreated controls). In contrast, NANOG mRNA levels were lower $(\mathrm{P}<0.05)$ in differentiated bMSC at Days 14, 24 and 21 of culture (1.2-. 0.86- and 0.97-fold relative to Day 0 vs. 8.6, 6.4- and 4.6-fold in untreated controls).

\section{Functional characterization of bMSC during hepatogenic differentiation}

More intense PAS staining associated to stored glycogen was observed in differentiated compared to control bMSC at Day 28 of culture (Figure 3A). At Days 21 and 28 of differentiation, higher $(\mathrm{P}<0.05)$ secretion of albumin (494.1 and $1213 \mu \mathrm{g} / \mathrm{mL}$ vs. 88.2 and $232.9 \mu \mathrm{g} / \mathrm{mL}$ in untreated controls) and urea concentration (7.3 and
$8.2 \mathrm{mg} / \mathrm{dL}$ vs. 4.7 and $5.6 \mathrm{mg} / \mathrm{dL}$ in untreated controls) were detected in differentiated bMSC cultures (Figure 3B).

\section{Gene expression profile in bMSC during neurogenic differentiation}

Protocol 1 used for neurogenic differentiation induced formation of compact and spherical cell bodies with multiple extensions since $96 \mathrm{~h}$ of culture (Figure 4A). No significant differences in mRNA levels of neural markers NESTIN, MAP2, NGF and TRKA were detected between bMSC cultured under differentiating and control conditions (Figure 4B). Protocol 2 induced cell body retraction and formation of multiple and complex cell extensions in differentiated bMSC since $96 \mathrm{~h}$ of culture (Figure 5A). These cells expressed NESTIN and MAP2 proteins at $0 \mathrm{~h}$ of culture; whereas, at $144 \mathrm{~h}$ also expressed TRKA and $\operatorname{PrP}^{\mathrm{C}}$ (Figure $5 \mathrm{~B}$ and $\mathrm{C}$ ). Differentiated bMSC expressed higher $(\mathrm{P}<0.05)$ levels of $M A P 2$ mRNA (22.8-fold relative to Day 0 vs. 0.42 -fold in untreated controls) at $144 \mathrm{~h}$ of culture (Figure $5 \mathrm{C}$ ). Similarly, levels of TRKA mRNA were higher $(\mathrm{P}<0.05)$ in differentiated bMSC at $96 \mathrm{~h}$ and $144 \mathrm{~h}$ of culture (51.4- and 111.2-fold relative to Day 0 vs. 23.1- and 31.3-fold in untreated controls). Conversely, differentiated bMSC expressed lower $(\mathrm{P}<0.05)$ mRNA levels of NANOG at $96 \mathrm{~h}$ and $144 \mathrm{~h}$ of culture (16.3- and 17.4fold relative to Day 0 vs. 47.9- and 25.8-fold in untreated controls). No significant differences were detected for NESTIN, NGF and $\operatorname{Pr} P^{C}$ mRNA levels between treated and untreated bMSC; however, both cell populations expressed higher $(\mathrm{P}<0.05)$ levels of NESTIN at $24 \mathrm{~h}$ of culture.
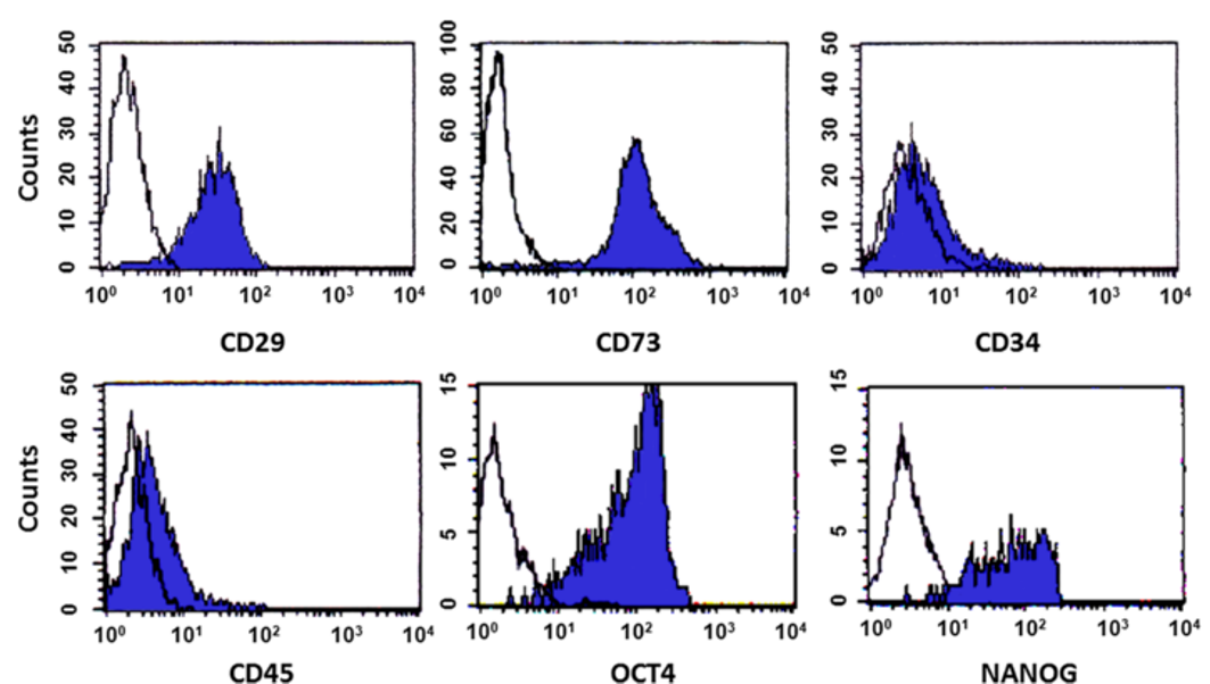

Figure 1 Flow cytometric analysis of bMSC isolated by plastic adherence from BM of abattoir-derived fetuses. Higher percentage ( $P<0.05)$ of bMSC (shaded region) was positive for MSC surface antigens CD29, CD73 and negative for hematopoietic markers CD34 and CD45. Similarly, the majority of MSC expressed pluripotent genes OCT4 and NANOG. Open region in each panel represent the control. 

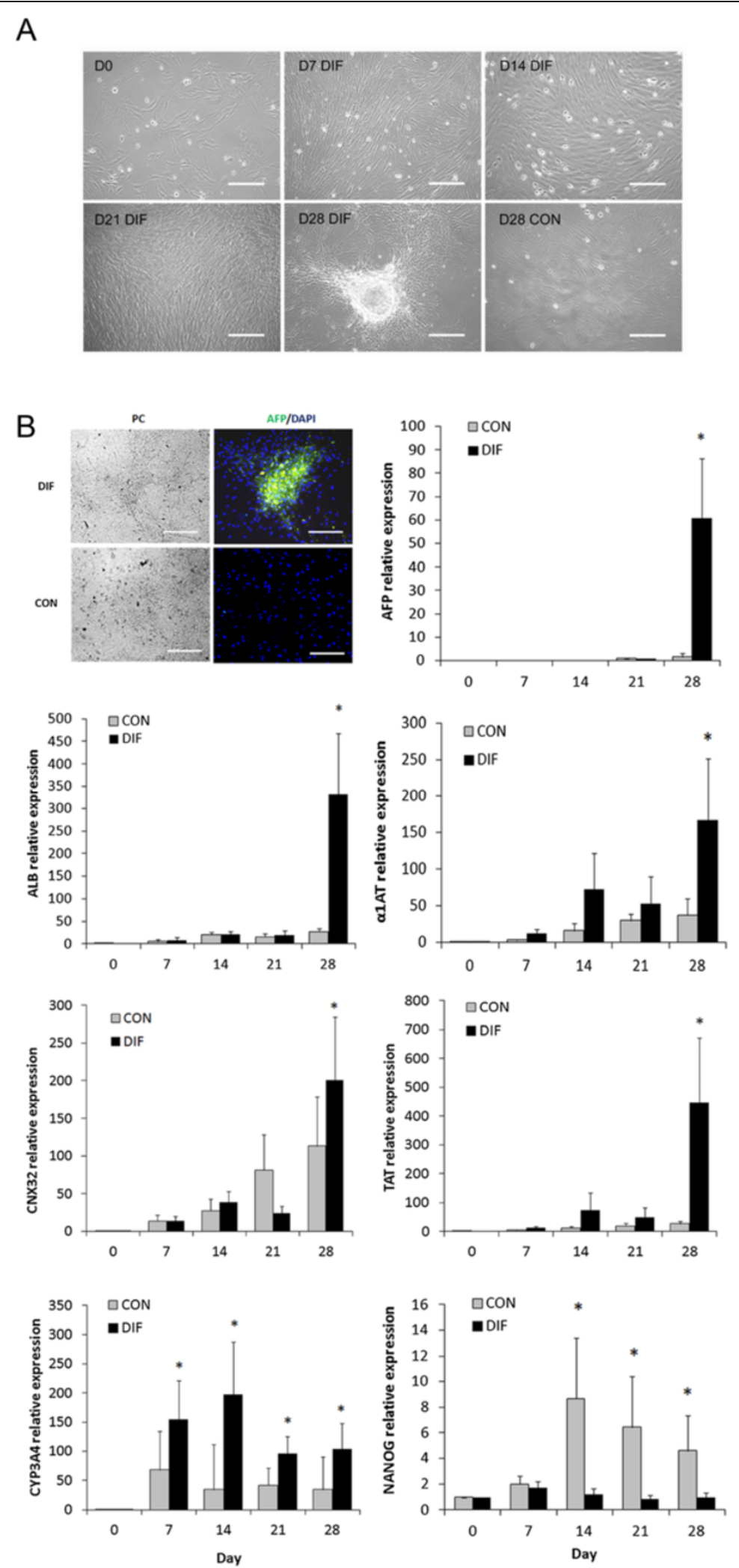

Figure 2 (See legend on next page.) 
(See figure on previous page.)

Figure 2 Hepatocyte and multipotent gene expression profile in bMSC under hepatogenic conditions during a 28-Day in vitro culture period. (A) bMSC were isolated by plastic adherence from bovine fetal BM and cultured under hepatogenic or control conditions. Culture of fetal bMSC under hepatogenic conditions stimulated cell replication at earlier stages and induced formation of polygonal cell morphology and cell aggregates at Day 28 of culture. (B) AFP protein was immunodetected in cell aggregates in differentiated (DIF) but not in control (CON) bMSC cultures at Day 28. AFP mRNA levels increased $(P<0.05)$ in differentiated bMSC at Day 28 of culture. Similarly, ALB, a1-AT, CNX32, and TAT and mRNA levels increased $(P<0.05)$ in differentiated bMSC at Day 28 of culture. Levels of CYP3A4 mRNA were higher $(P<0.05)$ in differentiated compared to control bMSC from Day 7 until Day 28 of culture. NANOG mRNA levels were lower $(P<0.05)$ in differentiated compared to control bMSC from Day 14 to Day 28 of culture. $\left(^{*}\right)$ Superscripts represent significant $(P<0.05)$ differences between treatments and sampling days. Bar scale: $500 \mu \mathrm{m}$.

\section{Discussion}

In the present study, bMSC were isolated from BM collected from abattoir-derived fetuses based on the capacity to adhere to plastic substrate under monolayer culture conditions. These cells expressed MSC specific markers CD29 and CD73 and lacked expression of hematopoietic surface markers CD34 and CD45. Little information is available regarding expression of MSC surface markers in bMSC. Analyses by flow cytometry in bMSC isolated from the Wharton's jelly detected high proportion of cells positive for CD29, CD73, CD90 and CD105 and negative for CD34 and CD45 [11]. Using Q-PCR, we reported a similar MSC marker profile in bMSC isolated from BM of abattoir-derived bovine fetuses [12]. Recently, these results have been confirmed by immunofluorescence and RT-PCR in bMSC isolated from fetal BM [23]. Thus, in vitro characterization presented in this study and in previous reports including adherence to plastic substrate, expression of mesenchymal markers and differentiation into mesodermal lineages suggests that bMSC isolated from fetal BM by plastic adherence fulfill the minimal criteria for definition of MSC.

The 2-step sequential hepatogenic differentiation protocol used in our study included early (EGF), middle (HGF), and late (OSM, dexamethasone, ITS and DMSO) differentiation factors [24]. HGF is an endocrine or paracrine factor essential for liver development that promotes cell survival and regeneration [25]. OSM is a member of the interleukin-6 cytokine family that increases cell size of hepatocytes and induces cell differentiation and formation of bile canaliculi [26]. The capacity to induce hepatocyte functions, albumin secretion and cytochrome activity may be enhanced when OSM is combined with DMSO [27]. Dexamethasone, a synthetic glucocorticoid that induces hepatic gluconeogenesis, promotes the expression of hepatocyte phenotype through the suppression of cell division [28]. The hepatogenic differentiation potential of fetal bMSC was evaluated using quantitative and qualitative analyses. Spindle shape and polygonal cell morphology observed at Day 28 in differentiated bMSC was not typical hepatocyte-like morphology described in previous studies. However, during mesenchyme-to-hepatocyte differentiation, expression of specific transcription factors of early endoderm, bipotential cells, and finally hepatocytes were up-regulated. It is recognized that AFP and ALB are abundant proteins synthesized from early fetal to adult mature hepatocytes $[29,30]$. TAT and $\alpha 1 \mathrm{AT}$ are liver-specific enzymes involved in degradation of tyrosine and inhibition of proteases, and are known to be late markers of the hepatocyte lineage $[31,32]$. CNX32 is a major gap junction protein which account for the $90 \%$ of connexin proteins in the liver [33]. Expression of these genes at the latest stage of differentiation indicates that prolonged exposure to hepatogenic factors is required in order to trigger the mesenchymal-to-hepatic transition. However, increasing levels of CYP3A4 mRNA Day 7 of culture suggest that activation of catalytic enzymes involved in the hepatic metabolism occurs at early stages of hepatogenic differentiation [34]. Moreover, production of albumin and urea at Days 21 and 28 of hepatogenic differentiation demonstrate the acquisition of hepatocyte metabolic activity in differentiated bMSC [35]. These results along with detection of glycogen storage indicate that bMSC underwent transdifferentiation into the endodermic hepatogenic lineage in agreement with the attainment of the hepatocyte gene expression profile.

In order to investigate the ectodermal differentiation potential, bMSC were induced toward neurogenic lineage using a previously reported BME-based protocol [17]. bMSC morphology including formation of compact cell bodies with multiple extensions along with expression of neural stem cell marker NESTIN and mature neuron markers MAP2, NGF and TRKA, initially suggested the acquisition of neural properties in treated bMSC. However, absence of neural marker increment in bMSC after treatment with a BME indicates that this simple chemical neuronal induction protocol was not able to induce neural differentiation. Previous studies have reported that BME-based protocols may induce neuronal phenotype in other cell types lacking any stem cell characteristics (fibroblasts, HEK 293 and PC12 cells) [36,37]. This neuron-like appearance was associated to disruption of cytoskeleton after cell stress due to toxic chemicals rather than cell differentiation.

A second protocol based on combination of growth factor pretreatment and induction with previously reported factors was assessed in fetal bMSC for neurogenic differentiation [38]. EGF-bFGF pretreatment have 


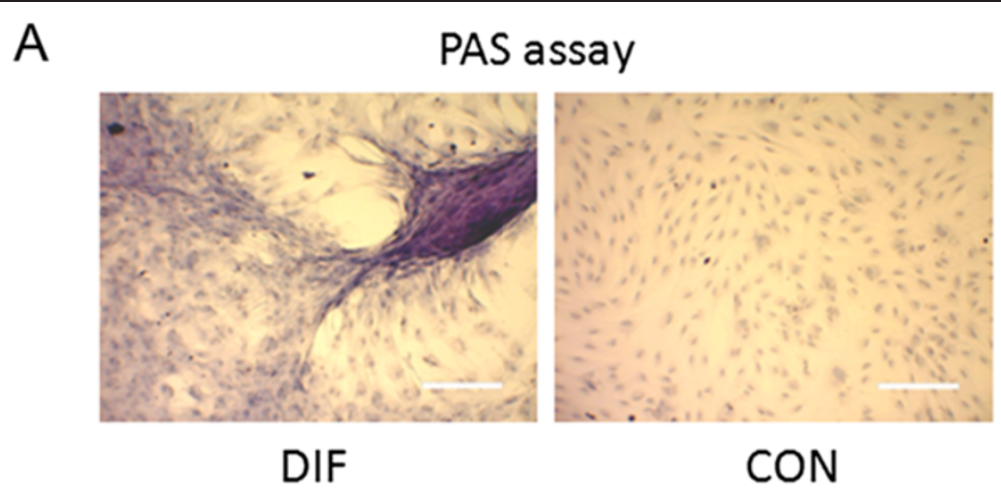

B
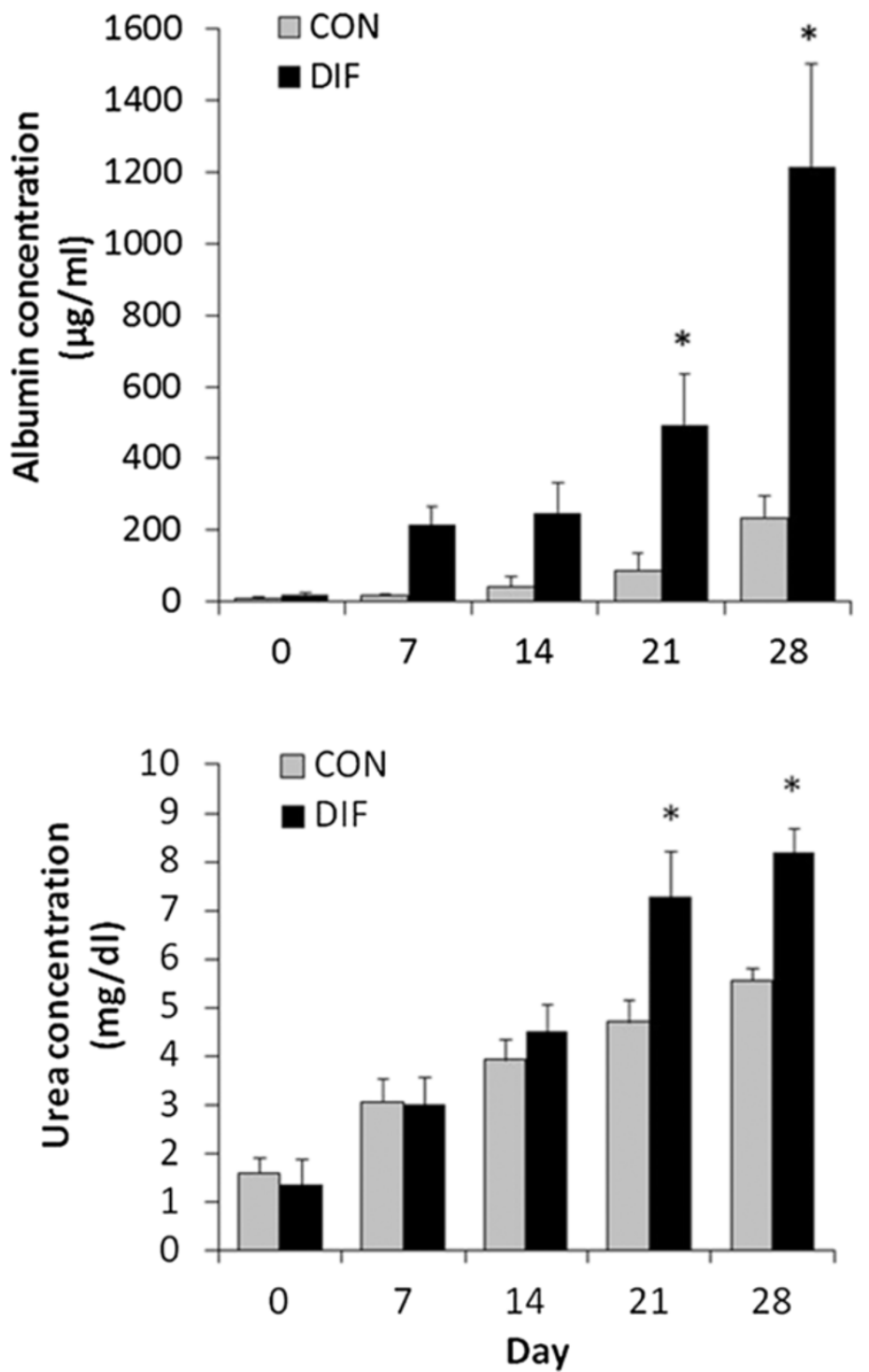

Figure 3 (See legend on next page.) 
(See figure on previous page.)

Figure 3 Functional hepatocyte characterization of bMSC under hepatogenic conditions during a 28-Day in vitro culture period.

(A) More intense positive PAS staining was observed in differentiated (DIF) compared to control (CON) bMSC cultures. (B) Production of albumin increased $(P<0.05)$ in differentiated bMSC cultures at Days 21 and 28 of hepatogenic differentiation. Similarly, levels of urea increased $(P<0.05)$ in differentiated bMSC at Days 21 and 28 of hepatogenic differentiation. $\left(^{*}\right)$ Superscripts represent significant $(P<0.05)$ differences between treatments. Bar scale: $500 \mu \mathrm{m}$.

A

B
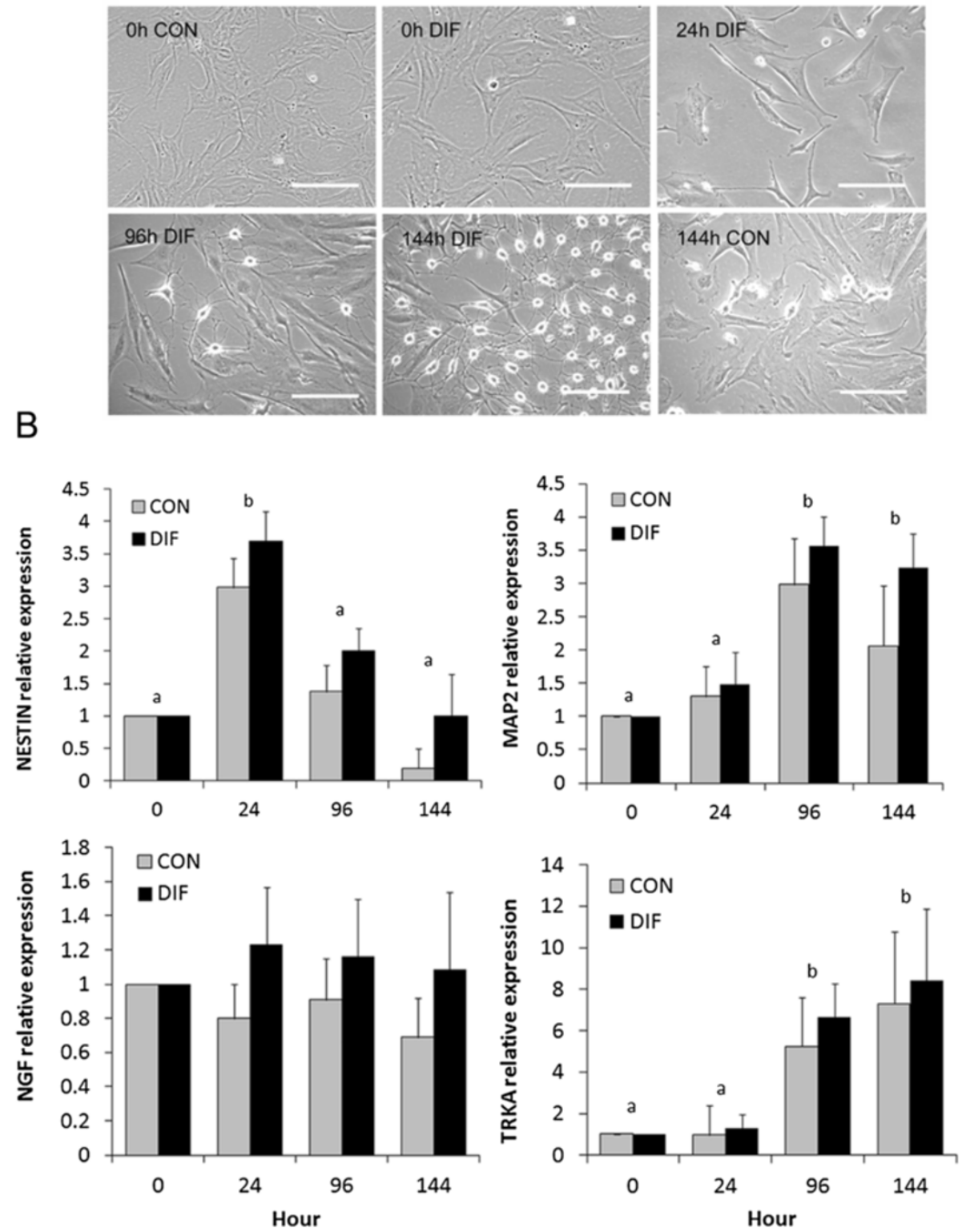

Figure 4 Neural and multipotent gene expression profile in bMSC under differentiating conditions using neurogenic protocol 1. (A) bMSC were isolated by plastic adherence from bovine fetal BM and cultured under neurogenic or control conditions. Culture of fetal bMSC under neurogenic conditions induced formation of cell body retraction and formation of multiple and complex extensions since $24 \mathrm{~h}$ of culture. (B) Analysis of Q-PCR detected mRNA levels of neural markers NESTIN, MAP2, NGF and TRKA in fetal bMSC cultured under control (CON) and differentiating (DIF) conditions. No differences $(P>0.05)$ in mRNA levels were detected between control and differentiated cultures. (a,b) Superscripts represent significant $(P<0.05)$ differences between sampling hour. Bar scale: $500 \mu \mathrm{m}$. 


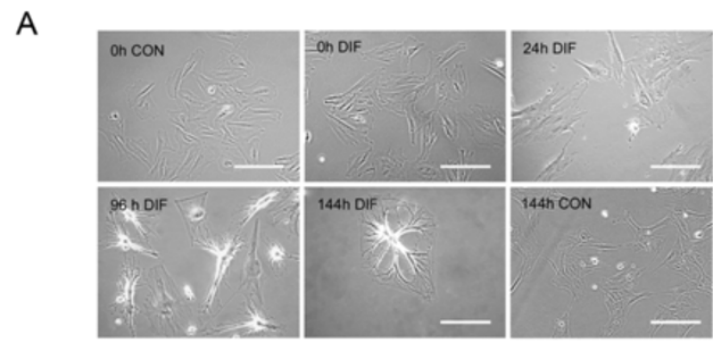

B

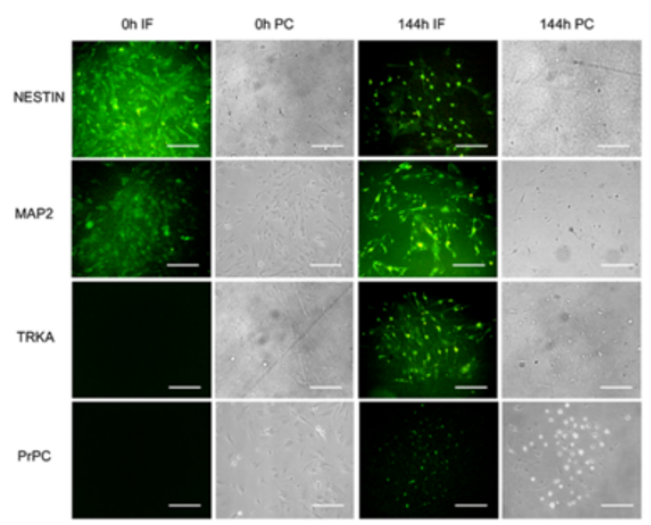

C
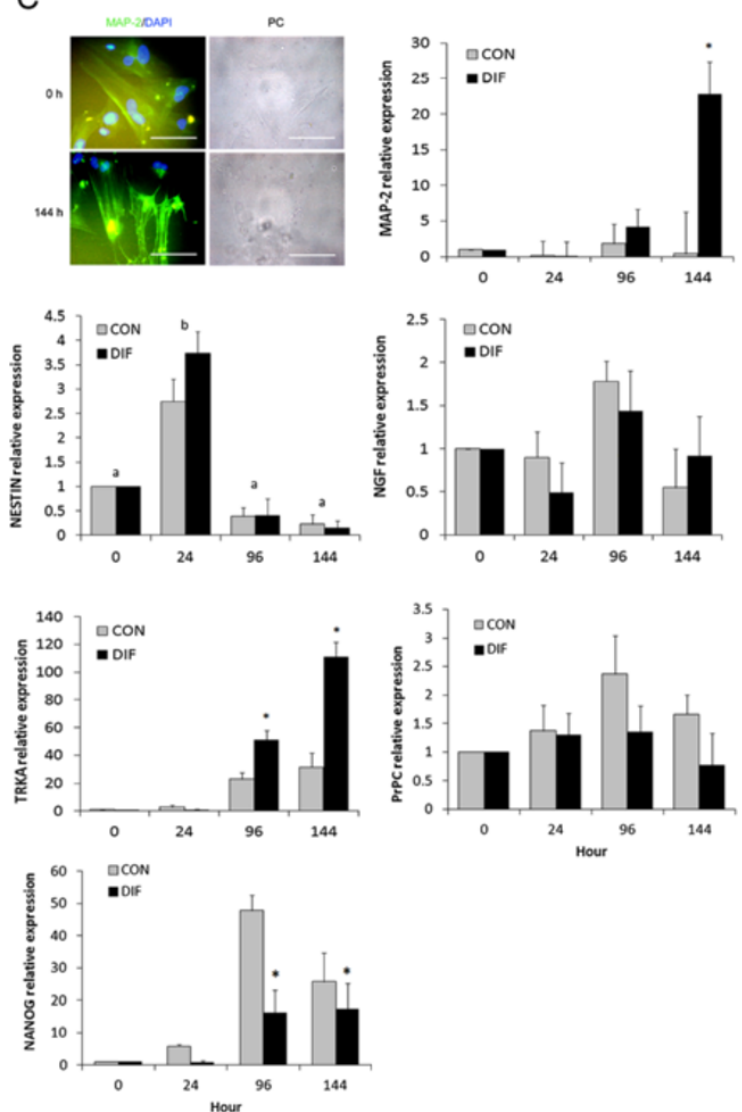

Figure 5 Neural gene expression profile in bMSC under differentiating conditions using neurogenic protocol 2 .

(A) Culture of fetal bMSC under neurogenic conditions induced formation of polygonal cell morphology and cell aggregates at Day 28 of culture. (B) At $24 \mathrm{~h}$ of culture, differentiated bMSC expressed both NESTIN and MAP2 proteins; whereas, at $144 \mathrm{~h}$ of culture also expressed TRKA and PrPC proteins. (C) MAP2 protein was immunodetected in cell cytoplasm associated to the cytoskeleton. Levels of MAP2 mRNA were up-regulated in differentiated (DIF) bMSC at $144 \mathrm{~h}$ of culture. In addition, these cells expressed higher $(P<0.05)$ levels of TRKA mRNA at 96 and $144 \mathrm{~h}$ of culture compared to controls. No differences in mRNA levels were detected for NESTIN, NGF and PrPC between differentiated and control bMSC cultures. NANOG mRNA levels were lower $(P<0.05)$ in differentiated compared to control bMSC from $96 \mathrm{~h}$ to $144 \mathrm{~h}$ of culture. $\left({ }^{*}\right.$, a,b) Superscripts represent significant $(P<0.05)$ differences between treatments and sampling days, respectively. Bar scale: $500 \mu \mathrm{m}$.

been associated to initiation of MSC cycle exit and activation of neural/neuronal gene expression pattern [39]. Thereafter, culture in differentiation medium containing KCL, valproic acid, forskolin and hydrocortisone has showed to induce neuronal morphological and immunocytochemical changes in human and murine adiposederived stem cells [38]. In our study, morphology changes in bMSC during culture were characterized by cell body retraction and formation of multiple and complex cell extensions that were consistent with neuronal differentiation. These cells expressed NESTIN and MAP2 at $24 \mathrm{~h}$ of culture, in addition with TRKA and $\operatorname{PrP}^{\mathrm{C}}$ after $144 \mathrm{~h}$ of culture. The capacity of MSC to coexpress immature and mature neuronal or glial proteins has been previously associated to the plasticity to differentiate in various tissues [40,41]. In our study, immunodetection of NESTIN, MAP2, TRKA and $\operatorname{PrP}^{\mathrm{C}}$ proteins, along with up-regulation of $M A P 2$ and TRKA mRNA in differentiated bMSC indicated that these cells were induced toward neural linage. However, a functional assay will be required before concluding that these cells have the potential to become neurons. Lack of significant differences in NESTIN, NGF and $\operatorname{PrP}^{C}$ mRNA levels between bMSC treatments were probably due to reduced level of expression of these genes. Constituently expression of NESTIN and MAP2 in MSC cultured without any previous induction, have been previously associated to the presence of a multidifferentiated state, in which MSC may retain a native potential for differentiation [42]. Previously, it have been reported that after in utero transplantation of human MSC in sheep or systemic infusion in baboons, MSC are found distributed in several tissues including gastrointestinal, kidney, liver, and skin [43,44]. These studies support the hypothesis [42] that subpopulations of MSC are in reality in a multidifferentiated state and participate in vivo in the turnover and replacement of a wide variety of tissues. Furthermore, these subpopulations may also explain the expression of lineage-specific markers in supposedly undifferentiated MSC populations. Although expression of NESTIN has been associated to early 
acquisition of neuronal lineage, expression in other cell type including myogenic, endothelial and hepatic suggest that this protein may not play a unique role in neurogenic differentiation [45]. Considering the proposed role of $\operatorname{PrP}^{C}$ in neural differentiation of embryonic stem cells (ESC) [46] and its participation in bovine spongiform encephalopathy (BSE) [47], transdifferentiation of MSC into neural cells could provide a valuable in vitro model for the study of prion diseases. Using co-localization analyses in the neuroepithelium of bovine fetuses and an in vitro differentiating ESC model, it has been shown that $\operatorname{PrP}^{\mathrm{C}}$ influences the differentiation of NESTIN-expressing cell lineages, including neural lineages [46]. These data provides clues of the complex signaling pathways that mediate ESC neural differentiation; however, further in vitro differentiation experiments would be required in order to elucidate if this interactions are similar in MSC.

The expression of pluripotent markers OCT4 and NANOG was analyzed with the aim to evaluate the state of multipotency in bMSC during mesenchymal differentiation. OCT4 and NANOG regulate the maintenance of pluripotent state in embryos and derived cells in most mammalian species $[48,49]$. These transcription factors had been proposed to play a similar role in adult stem cells [50]. However, recent reports have indicated that NANOG expression is associated to adaptation to in vitro cell growth conditions in differentiating MSC [51,12]. In our study, the patterns of expression of OCT4 and NANOG in undifferentiated MSC support the potential participation of these factors during the multipotent state. Moreover, our data suggest that the multipotent capacity of bMSC is reduced according to the acquisition of the hepatogenic phenotype and functional activity.

\section{Conclusions}

The expression patterns of lineage-specific markers and the production of functional metabolites demonstrate the acquisition of hepatocyte and neuronal profiles in bMSC after independent in vitro hepatogenic and neurogenic independent differentiations. The simplicity of isolation and the potential to differentiate into several cell types lays the foundation for BM MSC isolated from abattoir-derived bovine fetuses, as an alternative source of MSC for investigation of biology and eventual applications for regenerative therapy in veterinary medicine.

\section{Methods}

All procedures have been approved by the Bioethical Committee of the National Commission for Scientific and Technology Research (Fondecyt).

Isolation and culture of bMSC from fetal bone marrow Bone marrow was aspirated from bovine fetuses $(n=10$; 7-8 months of gestation) collected at a local abattoir.
The marrow was drawn from femoral marrow cavity into syringes containing high glucose Dulbecco's Modified Eagle Medium (DMEM, Gibco, Grand Islands, NY, USA) supplemented with $10 \%$ fetal bovine serum (FBS), $1000 \mathrm{U}$ heparin, $100 \mathrm{U} / \mathrm{mL}$ penicillin and $100 \mu \mathrm{g} / \mathrm{mL}$ streptomycin. Bone marrow samples were washed twice with phosphate-buffered saline (PBS) and twice with DMEM. Then cells were plated in DMEM (high glucose) supplemented with $10 \% \mathrm{FBS}, 100 \mathrm{U} / \mathrm{mL}$ penicillin, $100 \mu \mathrm{g} /$ $\mathrm{mL}$ streptomycin and $0.25 \mu \mathrm{g} / \mathrm{mL}$ amphotericin B. Cells were incubated at $38^{\circ} \mathrm{C}$ in a humidified atmosphere containing $5 \% \mathrm{CO}_{2}$. Non-adherent cells were removed by changing the culture medium after 4 days. Following the initial 4 days, the medium was changed every 2-3 days. After 4 to 5 passages, cells were gently harvested when $90 \%$ confluent using $0.25 \%$ trypsin in $0.1 \%$ EDTA and used for differentiation experiments.

\section{Hepatogenic differentiation}

Induction of hepatogenic differentiation was performed using an adapted protocol from a previously published report [24]. Cells $\left(3 \times 10^{3} / \mathrm{cm}^{2}\right)$ at passages 3 to 5 were plated in T-25 culture dishes either in control or differentiation medium. Control medium consisted of DMEM (low glucose) supplemented with 5\% FBS, $100 \mathrm{U} / \mathrm{mL}$ penicillin, $100 \mu \mathrm{g} / \mathrm{mL}$ streptomycin and $0.25 \mu \mathrm{g} / \mathrm{mL}$ amphotericin B. bMSC were cultured in control medium for 1 week followed by culture in FBS-free control medium for three weeks. Differentiation was induced by treating bMSC with Step-1 differentiation medium consisting in 57.5\% DMEM (low glucose) and 37.5\% MCDB-201 (SigmaAldrich, St. Louis, MO, USA) supplemented with $1 \mathrm{x}$ ITS (BD Biosciences, San Jose, CA, USA), $1 \mathrm{nM}$ dexamethasone, $0.1 \mathrm{mM}$ ascorbic acid 2-phosphate (Sigma), $10 \mathrm{ng} / \mathrm{mL}$ rhEGF (BD Biosciences), $100 \mu \mathrm{g} / \mathrm{mL}$ streptomycin, $100 \mathrm{U} /$ $\mathrm{mL}$ penicillin, $2.5 \mu \mathrm{g} / \mathrm{mL}$ amphotericin $\mathrm{B}$ and $5 \% \mathrm{FBS}$ for 7 days. Thereafter, bMSC were treated with Step-2 differentiation medium consisting in Step-1 differentiation medium supplemented with 0.1\% DMSO (Calbiochem, Darmstadt, Germany), $10 \mathrm{ng} / \mathrm{mL}$ rhHGF (Sigma) and $10 \mathrm{ng} / \mathrm{mL}$ rhOSM (Sigma) for 21 days. Medium change was performed every other day and cell samples were obtained from control and differentiation bMSC at Days 0, 7, 14 and 21 of culture and analyzed for $\beta$-ACTIN, AFP, ALB, Q1AT, CNX32, TAT, CYP3A4 and NANOG expression by Q-PCR.

\section{Neurogenic differentiation}

Induction of neurogenic differentiation was performed using adapted protocols from previously published reports $[17,38]$. Cells $\left(5 \times 10^{3} / \mathrm{cm}^{2}\right)$ at passages 3 to 5 were plated in T-25 culture dishes either in control or differentiation medium. Control medium consisted of DMEM (low glucose) supplemented with $100 \mathrm{U} / \mathrm{mL}$ penicillin, 
$100 \mu \mathrm{g} / \mathrm{mL}$ streptomycin and $0.25 \mu \mathrm{g} / \mathrm{mL}$ amphotericin B. In protocol 1 , bMSC were cultured in a pre-induction medium consisting in DMEM (high glucose) supplemented with $20 \%$ FBS, $1 \mathrm{mM} \beta$-mercaptoethanol (BME, Sigma), $100 \mathrm{U} / \mathrm{mL}$ penicillin, $100 \mu \mathrm{g} / \mathrm{mL}$ streptomycin and $0.25 \mu \mathrm{g} / \mathrm{mL}$ amphotericin B. After $24 \mathrm{~h}, \mathrm{MSC}$ were cultured in induction medium consisting in DMEM (high glucose) supplemented with $1 \mathrm{mM}$ BME, $100 \mathrm{U} /$ $\mathrm{mL}$ penicillin, $100 \mu \mathrm{g} / \mathrm{mL}$ streptomycin and $0.25 \mu \mathrm{g} / \mathrm{mL}$ amphotericin B. In protocol 2, MSC were cultured in a pre-induction medium consisting in DMEM (high glucose) supplemented with 20\% FBS, $10 \mathrm{ng} / \mathrm{mL}$ bFGF (BD Biosciences), $20 \mathrm{ng} / \mathrm{mL}$ EGF (BD Biosciences), $100 \mathrm{U} /$ $\mathrm{mL}$ penicillin, $100 \mu \mathrm{g} / \mathrm{mL}$ streptomycin and $0.25 \mu \mathrm{g} / \mathrm{mL}$ amphotericin B. After $24 \mathrm{~h}$, bMSC were cultured in induction medium consisting in DMEM (high glucose) supplemented with $200 \mu \mathrm{M}$ BME, $25 \mathrm{mM}$ KCL, $2 \mathrm{mM}$ valproic acid, $10 \mu \mathrm{M}$ forskolin, $1 \%$ neural supplement (N1) (All from Sigma), $100 \mathrm{U} / \mathrm{mL}$ penicillin, $100 \mu \mathrm{g} / \mathrm{mL}$ streptomycin and $0.25 \mu \mathrm{g} / \mathrm{mL}$ amphotericin B. Cells were cultured for a total period of 6 days at $38^{\circ} \mathrm{C}$ under a humidified atmosphere containing $5 \% \mathrm{CO}_{2}$. Medium change was performed every other day and cell samples were obtained from control and differentiation bMSC at $0,24,96$ and $144 \mathrm{~h}$ of culture and analyzed for glyceraldehyde-3-phosphate dehydrogenase (GAPDH), NESTIN, MAP2, NGF, TRKA, PrP ${ }^{C}$ gene expression.

\section{Flow cytometry}

The expression of CD29, CD34, CD45, CD73, OCT4 and NANOG was detected in bMSC using flow cytometry. Cells were removed from culture dishes using $5 \mathrm{mM}$ EDTA for $10 \mathrm{~min}$ at $38^{\circ} \mathrm{C}$. Then cells were permeabilized using a Foxp3 kit (eBioscience, San Diego, CA, USA) by incubation at room temperature for $5 \mathrm{~min}$ with shaking. Then cells were centrifuged at 2000 RPM for $5 \mathrm{~min}$ and then in $2 \%$ normal rabbit serum in PBS. Then bMSC were incubated in a 1:100 goat primary polyclonal antibody (CD34, CD73, OCT4 and NANOG; Santa Cruz Biotechnology, Santa Cruz, CA, USA) or rabbit primary monoclonal antibody (CD29 and CD45; Santa Cruz Biotechnology) for $30 \mathrm{~min}$ on ice with shaking. Then cells were washed with PBS and centrifuged 2000 RPM for $5 \mathrm{~min}$. The pellet was resuspended in $1.5 \mathrm{~mL}$ of PBS and 1:100 donkey anti-goat or anti-mouse secondary antibodies (Santa Cruz Biotechnology) and incubated for $30 \mathrm{~min}$ on ice. After 3 washes on PBS, the pellet was resuspended on cytometry buffer and analyzed using a FACS Calibur flow cytometer (BD Bioscience) using a $488 \mathrm{~nm}$ (blue) and $633 \mathrm{~nm}$ (red) laser light. The signal was analyzed using a Cellquest program (BD Bioscience). The threshold for negative events was set on the first decade of fluorescence level. Negative procedural control corresponded to replacement of secondary antibody with non-immune serum.

\section{RNA extraction and cDNA synthesis}

Cells were collected and immediately fixed in RLT buffer (Qiagen, Incorporated, Valencia, CA, USA). Total RNA was extracted using RNeasy Mini kit (Qiagen) following manufacturer's recommendations. The concentration and purity of the RNA in each sample were determined using spectrophotometry (BioRad Laboratories, Hercules, CA, USA). Total RNA was eluted in $30-50 \mu \mathrm{L}$ of RNase free water. Samples were subjected to RT-PCR using Brilliant II SYBR Green RT-PCR kit (Agilent). The reaction protocol consisted of incubation for $5 \mathrm{~min}$ at $25^{\circ} \mathrm{C}, 15 \mathrm{~min}$ at $42^{\circ} \mathrm{C}$, $5 \mathrm{~min}$ at $95^{\circ} \mathrm{C}$ and hold at $4^{\circ} \mathrm{C}$ using a DNA engine PCR thermocycler (BioRad).

\section{Quantitative-PCR}

Real-time PCR primers were designed using PrimerExpress software (Applied Biosystems Incorporated, Foster City, CA) (Table 1). Equivalence of amplification efficiencies among all primer-probe sets was confirmed using serial 3-fold dilutions of differentiated bMSC cDNA. Each RT-PCR reaction $(25 \mu \mathrm{L})$ contained the following: 2X Brilliant II SYBR Green QPCR master mix $(12.5 \mu \mathrm{L})$, diluted reference dye $(0.375 \mu \mathrm{L})$, target forward primer $(200 \mathrm{nM})$, target reverse primer $(200 \mathrm{nM})$, cDNA synthesis reaction $(2 \mu \mathrm{L})$ and nuclease-free PCRgrade water to adjust final volume. The PCR amplification was carried out in StepOne Real Time PCR System (Applied Biosystems). Thermal cycling conditions were $95^{\circ} \mathrm{C}$ for $10 \mathrm{~min}$, followed by 40 repetitive cycles at $95^{\circ} \mathrm{C}$ for $30 \mathrm{sec}$ and $60^{\circ} \mathrm{C}$ for $1 \mathrm{~min}$. As a normalization control for RNA loading, parallel reactions in the same multiwell plate were performed using GAPDH or $\beta$-ACTIN as a target. Quantification of gene amplification was made following Q-PCR by determining the threshold cycle $\left(\mathrm{C}_{\mathrm{T}}\right)$ number for SYBR fluorescence within the geometric region of the semilog plot generated during PCR. Within this region of the amplification curve, each difference of one cycle is equivalent to a doubling of the amplified product of the PCR. The relative quantification of the target gene expression across treatment was evaluated using the comparative $\Delta \Delta C_{T}$ method. The $C_{T}$ value was determined by subtracting the most stable endogenous gene $C_{\mathrm{T}}$ value $(\beta$-ACTIN hepatogenesis; $G A P D H$, neurogenesis) from the target $C_{\mathrm{T}}$ value of the sample. Calculation of $\Delta \Delta C_{T}$ involved using target gene expression on Day 0 (Sample with the highest CT value or lowest target expression) as an arbitrary constant to subtract from all other $\mathrm{C}_{\mathrm{T}}$ sample values. Relative target mRNA expression was calculated as fold changes in relation to Day or Hour 0 sample and expressed as $2^{-\Delta \Delta C T}$ value.

\section{Immunofluorescence}

Differentiated and control bMSC were fixed in a $4 \%$ paraformaldehyde (PAF) for $10 \mathrm{~min}$ and permeabilized 
Table 1 Sequence of primers used for Q-PCR analysis

\begin{tabular}{|c|c|c|c|}
\hline Gene & Sense & Antisense & Accession number \\
\hline \multicolumn{4}{|c|}{ Housekeeping } \\
\hline GAPDH & 5' CCTTCATTGACCTTCACTACATGGTCTA & 5' TGGAAGATGGTGATGGCCTITCCATTG & NM 001034034.2 \\
\hline BACTIN & 5' CGCACCACTGGCATTGTCAT & 5' TCCAAGGCGACGTAGCAGAG & K00622.1 \\
\hline \multicolumn{4}{|c|}{ Hepatogenic } \\
\hline AFP & 5' CTTGTTGCTTACACAAAGAAGG & 5' ATGGAAGATGAACTTGTCATCG & NM 001034262.2 \\
\hline ALB & $5^{\prime}$ TITCTCAGTATCTCCAGCAGT & 5' AGTAGGGATGTCTTCTAGCAAT & NM 180992.2 \\
\hline a1AT & 5' GCTGGGGTTCTCCAAGGAC & 5' GTTTGCTCATTCACGTGGAAGTC & NM 173882.2 \\
\hline CNX32 & 5' ATGAACTGGACAGGTTGTAC & 5' ATGTGTTGCTGGTGAGCCA & NM 174069.2 \\
\hline CYP3A4 & 5' ATCATTGCTGTCTCCAACCTTCAC & 5' TGCTTCCCGCCTCAGATTTCTC & NM 001099367.1 \\
\hline TAT & 5' TाTGCTATGGAGCTTGGCTGC & 5' AATGGTAGTGCAGCTCGCAGAA & NM 001034590.1 \\
\hline \multicolumn{4}{|c|}{ Neurogenic } \\
\hline NESTIN & 5' CTGGAGCAGGAGAAACAAGG & 5' GAAAGGTTGGCACAGGTGTT & NM 001206591.1 \\
\hline MAP2 & 5' CCACCTGAGATTAAGGATCA & 5' GGCTTACTTTGCTTCTCTGA & NM 001205807.1 \\
\hline NGF & $5^{\prime}$ TCAACAGGACTCACAGGAGCAA & 5' ACCTCTCCCAGCACCATCAC & NM 001099362.1 \\
\hline TRKA & 5' CTGGGTGAGGGTGCCTIT & 5' CGCTCTCAGACACCTCCTTCAG & XM 002685965.3 \\
\hline $\operatorname{PrPC}$ & 5' CCAGAGACACAAATCCAACTTGAG & 5' AACCAGGATCCAACTGCCTATG & NM 001271626.1 \\
\hline \multicolumn{4}{|c|}{ Pluripotency } \\
\hline NANOG & 5' GTGTTTGGTGAACTCTCCTG & 5' GGGAATTGAAATACTTGACAG & NM 001025344.1 \\
\hline
\end{tabular}

with $0.1 \%$ Triton X-100 for 10 minutes. Cells were then rinsed twice in PBS and blocked in donkey serum (Sigma) for $30 \mathrm{~min}$ at RT. Cells were incubated overnight at $4^{\circ} \mathrm{C}$ with primary mouse monoclonal anti AFP or $\operatorname{PrP}^{\mathrm{C}}$ antibody (1:50; Santa Cruz Biotechnology and Cayman Chemical, Ann Arbor, MI) or primary goat polyclonal anti NESTIN, MAP2, TRKA antibody (1:50; Santa Cruz Biotechnology) diluted in donkey serum. Then cells were rinsed three times with PBS and incubated with goat anti-mouse or anti-goat IgG conjugated to FITC (1:200 in donkey serum) for 45 minutes. Then cells were again rinsed three times in PBS and mounted under coverslips in a solution containing 4', 6diamidino-2-phenylindole (Santa Cruz Biotechnology). Samples were examined under epifluorescence and the results captured by digital photomicroscopy (Olympus, Tokyo, Japan).

\section{Periodic Acid-Schiff (PAS)}

Glycogen storage was evaluated in differentiated and control bMSC using PAS staining. Culture dishes containing cells were fixed in $4 \%$ paraformaldehyde for 10 min. Cells were rinsed 3 times in deionized (d) $\mathrm{H}_{2} \mathrm{O}$ and treated with $0.5 \%$ periodic acid for $5 \mathrm{~min}$ at $\mathrm{RT}$. Then cells were rinsed 3 times in $\mathrm{dH}_{2} \mathrm{O}$, treated with Schiff's reagent for 15 minutes, and rinsed 3 times in $\mathrm{dH}_{2} \mathrm{O}$. Samples were counterstained with Mayer's hematoxylin for 1 minute and rinsed in $\mathrm{dH}_{2} \mathrm{O}$ and assessed under light microscope.

\section{Urea assay}

Urea concentrations were determined in media collected from control and differentiated bMSC cultures by colorimetric assay (Bioclin, Quibasa Quimica, Santa Branca, Brazil) following manufacturer's recommendations and analyzed with spectrophotometer.

\section{Albumin assay}

Albumin concentrations were determined in media collected from control and differentiation MSC cultures by Bromocresol green colorimetric assay (Biosystem, Barcelona, Spain) following manufacturer's recommendations and analyzed with spectrophotometer.

\section{Data analysis}

Values of gene expression from four different replicates were transferred to a spreadsheet and then analyzed using Infostat software. Data was normalized to logarithmic scale in base 10 for normality and mean values for each replicate were compared by one-way ANOVA. Gene expression values between days of culture and between treatments and controls were analyzed using Duncan's multiple comparison test $(\mathrm{P}<0.05)$. 


\section{Abbreviations}

bMSC: Bovine mesenchymal stem cell; CD73: Ecto-5'-nucleotidase; CD90: Thy-1; CD105: Endoglin; CD45: Protein tyrosine phosphatase; C: Receptor type; CD34: CD34 molecule; AFP: a-fetoprotein; ALB: Albumin; a1AT: Alpha1 antitrypsin; CNX32: Connexin 32; TAT: Tyrosine aminotransferase: CYP3A4: Cytochrome P450; NESTIN: Neuroepithelial stem cell intermediate filament; MAP2: Microtubule associated protein 2; NGF: Nerve growth factor; TRKA: Tropomyosin-related kinase A: PrPC. Cellular prion protein; bFGF: Bovine fibroblast growth factor; EGF: Epidermal growth factor; FBS: Fetal bovine serum; Q-PCR: Quantitative-polymerase chain reaction.

\section{Competing interests}

The authors declare that they have no competing interests.

\section{Authors' contributions}

$F D, V B$ and $Y C$ performed cell isolation and culture expansion, hepatogenic and neurogenic differentiation assays, statistical analyses and helped in the manuscript drafting. SV and LS participated in the gene expression and functional analyses. JP and MDR helped in the epifluorescence microscopy and in the manuscript drafting. OAP conceived and designed the study, analyzed the data and drafted the manuscript. All authors read and approved the final manuscript.

\section{Acknowledgements}

This study was supported by grant 11100205 from the National Commission for Scientific and Technology Research (Fondecyt) from the Ministry of Education, Government of Chile. We would like to thanks Meat Processing Plant Cordillera for providing bovine fetuses for this study.

\section{Author details}

'Departamento de Fomento de la Producción Animal, Facultad de Ciencias Veterinarias y Pecuarias, Universidad de Chile, Santiago, Chile. ${ }^{2}$ Departamento de Ciencias Biológicas Animales, Facultad de Ciencias Veterinarias y Pecuarias, Universidad de Chile, Santiago, Chile. ${ }^{3}$ Department of Biomedical Sciences and Pathobiology, Virginia-Maryland Regional College of Veterinary Medicine, Virginia Polytechnic Institute and State University, Blacksburg, VA 24061-0442, USA.

Received: 26 March 2014 Accepted: 19 June 2014 Published: 10 July 2014

\section{References}

1. Pittenger MF, Mackay AM, Beck SC, Jaiswal RK, Douglas R, Mosca JD, Moorman MA, Simonetti DW, Craig S, Marshak DR: Multilineage potential of adult human mesenchymal stem cells. Science 1999, 284:143-147.

2. Harichandan A, Bühring MJ: Prospective isolation of human MSC Best Pract Res Clin Haematol 2011, 24:25-36.

3. Dominici M, Le Blanc K, Mueller I, Slaper-Cortenbach I, Marini FC, Krause DS, Deans RJ, Keating A, Prockop DJ, Horwitz EM: Minimal criteria for defining multipotent mesenchymal stromal cells. The International Society for Cellular Therapy position statement. Cytotherapy 2006, 8:315-317.

4. Bosch P, Pratt SL, Stice SL: Isolation, characterization, gene modification, and nuclear reprogramming of porcine mesenchymal stem cells. Biol Reprod 2006, 74:46-57.

5. Patterson-Kane JC, Becker DL, Rich T: The pathogenesis of tendon microdamage in athletes: the horse as a natural model for basic cellular research. J Comp Pathol 2012, 147:227-247.

6. Aerssens J, Boonen S, Lowet G, Dequeker J: Interspecies differences in bone composition, density, and quality: potential implications for in vivo bone research. Endocrinology 1998, 139:663-670.

7. Bosnakovski D, Mizuno M, Kim G, Takagi S, Okumura M, Fujinaga T: Isolation and multilineage differentiation of bovine marrow mesenchymal stem cells. Cell Tissue Res 2005, 319:243-253.

8. Bucher C, Gazdhar A, Benneker LM, Geiser T, Gantenbein-Ritter B: Nonviral gene delivery of growth and differentiation factor 5 to human mesenchymal stem cells injected into a 3D bovine intervertebral disc organ culture system. Stem Cells Int 2013, 2013:326828.

9. Colleoni S, Donofrio G, Lagutine I, Duchi R, Galli C, Lazzari G: Establishment, differentiation, electroporation, viral transduction, and nuclear transfer of bovine and porcine mesenchymal stem cells. Cloning Stem Cells 2005, 7:154-166.

10. Raoufi MF, Tajik P, Dehghan MM, Eini F, Barin A: Isolation and differentiation of mesenchymal stem cells from bovine umbilical cord blood. Reprod Domest Anim 2010, 46:95-99.

11. Cardoso TC, Ferrari HF, Garcia AF, Novais JB, Silva-Frade CS, Ferrarezi MC, Andrade AL, Gameiro R: Isolation and characterization of wharton's jellyderived multipotent mesenchymal stromal cells obtained from bovine umbilical cord and maintained in a defined serum-free three-dimensional system. BMC Biotechnol 2012, 12:18

12. Cortes $Y$, Ojeda $M$, Araya $D$, Dueñas F, Fernández MS, Peralta OA: Isolation and multilineage differentiation of bone marrow mesenchymal stem cells from abattoir-derived bovine fetuses. BMC Vet Res 2013, 9:133.

13. Zhang ZY, Teoh SH, Chong MS, Schantz JT, Fisk NM, Choolani MA, Chan J: Superior osteogenic capacity for bone tissue engineering of fetal compared with perinatal and adult mesenchymal stem cells. Stem Cells 2009, 27:126-137.

14. Zhang ZY, Teoh SH, Hui JHP, Fisk NM, Choolani M, Chan JKY: The potential of human fetal mesenchymal stem cells for off-the-shelf bone tissue engineering application. Biomaterials 2012, 33:2656-2672.

15. Capuco AV, Evock-Clover CM, Minuti A, Wood DL: In vivo expansion of the mammary stem/progenitor cell population by xanthosine infusion. Exp Biol Med 2009, 234:475-482.

16. Sharma N, Jeong DK: Stem cell research: a novel boulevard towards improved bovine mastitis management. Int Biol Sci 2013, 9:818-829.

17. Woodbury D, Schwarz E, Prockop D, Black I: Adult rat and human bone marrow stromal cells differentiate into neurons. J Neurosci Res 2000, 61:364-370.

18. Lee KD, Kuo TK, Whang-Peng J, Chung YF, Lin CT, Chou SH, Chen JR, Chen YP, Lee OK: In vitro hepatic differentiation of human mesenchymal stem cells. Hepatology 2004, 40:1275-1284.

19. Lee HJ, Jung J, Cho KJ, Lee CK, Hwang SG, Kim G: Comparison of in vitro hepatogenic differentiation potential between various placenta-derived stem cells and other adult stem cells as an alternative source of functional hepatocytes. Differentiation 2012, 84:223-231.

20. Jiang $Y$, Henderson D, Blackstad M, Chen A, Miller RF, Verfaillie CM: Neuroectodermal differentiation from mouse multipotent adult progenitor cells. Proc Natl Acad Sci USA 2003, 100:11854-11860.

21. Long $X$, Olszewski M, Huang W, Kletzel M: Neural cell differentiation in vitro from adult human bone marrow mesenchymal stem cells. Stem Cells Dev 2005, 14:65-69.

22. Lyahyai J, Mediano DR, Ranera B, Sanz A, Remacha AR, Bolea R, Zaragoza P, Rodellar C, Martin-Burriel I: Isolation and characterization of ovine mesenchymal stem cells derived from peripheral blood. BMC Vet Res 2012, 8:169

23. Lu T, Huang Y, Wang H, Ma Y, Guan W: Multi-lineage potential research of bone marrow-derived stromal cells (BMSCs) from cattle. Appl Biochem Biotechnol 2014, 172:21-35

24. Seo MJ, Suh SY, Bae YC, Jung JS: Differentiation of human adipose stromal cells into hepatic lineage in vitro and in vivo. Biochem Biophys Res Commun 2005, 328:258-264.

25. Schmidt C, Bladt F, Goedecke S, Brinkmann V, Zschiesche W, Sharpe M, Gherardi E, Birchmeier C: Scatter factor/hepatocyte growth factor is essential for liver development. Nature 1995, 373:699-702.

26. Lazaro CA, Croager EJ, Mitchell C, Campbell JS, Yu C, Foraker J, Rhim JA, Yeoh GC, Fausto N: Establishment, characterization, and long-term maintenance of cultures of human fetal hepatocytes. Hepatology 2003, 38:1095-1106.

27. Sakai Y, Jiang J, Kojima N, Kinoshita T, Miyajima A: Enhanced in vitro maturation of fetal mouse liver cells with oncostatin $\mathrm{M}$, nicotinamide, and dimethyl sulfoxide. Cell Transplant 2002, 11:435-441.

28. Oyadomari S, Matsuno F, Chowdhury S, Kimura T, Iwase K, Araki E, Scichiri M, Mori M, Takiguchi M: The gene for hepatocyte nuclear factor (HNF)-4a is activated by glucocorticoids and glucagon, and repressed by insulin in rat liver. FEBS Lett 2000, 478:141-146.

29. Shiojiri N: Enzymo and inmunocytochemical analyses of the differentiation of liver cells in prenatal mouse. J Embryol Exp Morphol 1981, 62:139-152.

30. Terentiev AA, Moldogazieva NT: Alpha-fetoprotein: a renaissance. Tumour Biol 2013, 34:2075-2091.

31. Rehman KK, Ayesha Q, Khan AA, Ahmed N, Habibullah CM: Tyrosine aminotransferase and gamma-glutamyl transferase activity in human 
fetal hepatocyte primary cultures under proliferative conditions. Cell Biochem Funct 2004, 22:89-96.

32. Jedicke N, Struever N, Aggrawal N, Welte T, Manns MP, Malek NP, Zender L, Janciauskiene S, Wuestefeld T: Alpha-1-Antitrypsin inhibits acute liver failure in mice. Hepatology 2014, 59:2299-2308.

33. Nakashima Y, Ono T, Yamanoi A, El-Assal ON, Kohno H, Nagasue N: Expression of gap junction protein connexin32 in chronic hepatitis, liver cirrhosis, and hepatocellular carcinoma. J Gastroenterol 2004, 39:763-768.

34. Scott EE, Halpert JR: Structure of cytochrome P450 3A4. Trends Biochem Sci 2005, 30:5-7.

35. Dunn JC, Tompkins RG, Yarmush ML: Long-term in vitro function of adult hepatocytes in a collagen sandwich configuration. Biotechnology Prog 1991, 7:237-245

36. Neuhuber B, Gallo G, Howard L, Kostura L, Mackay A, Fischer I: Reevaluation of in vitro differentiation protocols for bone marrow stromal cells: disruption of actin cytoskeleton induces rapid morphological changes and mimics neuronal phenotype. J Neurosci Res 2004, 77:192-204.

37. Lu P, Blesch A, Tuszynski MH: Induction of bone marrow stromal cells to neurons: differentiation, transdifferentiation, or artifact? J Neurosci Res 2004, 77:174-191.

38. Safford KM, Hicok KC, Safford SD, Halvorsen YDC, Wilkison WO, Gimble JM Rice HE: Neurogenic differentiation of murine and human adiposederived stromal cells. Biochem Biophys Res Commun 2002, 294:371-379.

39. Delcroix GJR, Curtis K, Schiller PC, Montero-Menei CN: EGF and bFGF pretreatment enhances neural specification and the response to neuronal commitment of MIAMI cells. Differentiation 2010, 80:213-227.

40. Sanchez-Ramos J, Song S, Cardozo-Pelaez F, Hazzi C, Stedeford T, Willing A, Freeman TB, Saporta S, Janssen W, Patel N, Cooper DR, Sanberg PR: Adult bone marrow stromal cells differentiate into neural cells in vitro. Exp Neurol 2000, 164:247-256.

41. Jiang $Y$, Jahagirdar BN, Reinhardt RL, Schwartz RE, Keene CD, Ortiz-Gonzales XR, Reyes M, Lenvik T, Lund T, Blackstad M, Du J, Aldrich S, Lisberg A, Low WC, Largaespada DA, Verfaillie CM: Pluripotency of mesenchymal stem cells derived from adult marrow. Nature 2002, 418:41-49.

42. Tondreau T, Lagneaux L, Dejeneffe M, Massy M, Mortier C, Delforge A, Bron D: Bone marrow-derived mesenchymal stem cells already express specific neural proteins before any differentiation. Differentiation 2004, 72:319-326.

43. Liechty KW, Mackenzie TC, Shaaban AF, Radu A, Moseley AM, Deans R, Marshak DR, Flake AW: Human mesenchymal stem cells engraft and demonstrate site-specific differentiation after in utero transplantation in sheep. Nat Med 2000, 6:1282-1286.

44. Devine SM, Cobbs C, Jennings M, Bartolomew A, Hoffman R: Mesenchymal stem cells distribute to a wide range of tissues following infusion into nonhuman primates. Blood 2003, 101:2999-3001.

45. Zuk PA, Zhu M, Mizuno H, Huang J, Futrell JW, Katz AJ, Benhaim P, Lorenz HP, Hedrick MH: Multilineage cells from human adipose tissue: implications for cell based therapies. Tissue Eng 2001, 7:211-228.

46. Peralta OA, Huckle WR, Eyestone WH: Expression and knockdown of cellular prion protein $(\mathrm{PrPC})$ in differentiating mouse embryonic stem cells. Differentiation 2011, 81:68-77.

47. Pan KM, Baldwin M, Nguyen J, Gasset M, Serban A, Groth D, Mehlhorn I, Huang Z, Fletterick RJ, Cohen FE, Prusiner SB: Conversion of alpha-helices into beta-sheets features in the formation of the scrapie prion proteins. Proc Natl Acad Sci USA 1993, 90:10962-10966.

48. Boyer LA, Lee TI, Cole MF, Johnstone SE, Levine SS, Zucker JP, Guenther MG, Kumar RM, Murray HL, Jenner RG, Gifford DK, Melton DA, Jaenisch R, Young RA: Core transcriptional regulatory circuitry in human embryonic stem cells. Cell 2005, 122:947-956.

49. Loh YH, Wu Q, Chew UL, Vega VB, Zhang W, Chen X, Bourque G, George J, Leong B, Liu J, Wong KY, Sung KW, Lee CW, Zhao XD, Chiu KP, Lipovich L, Kuznetsov VA, Robson P, Stanton LW, Wei CL, Ruan Y, Lim B, Ng HH: The Oct4 and Nanog transcription network regulates pluripotency in mouse embryonic stem cells. Nat Genet 2006, 38:431-440.

50. Riekstina U, Cakstina I, Parfejevs V, Hoogduijn M, Jankovskis G, Muiznieks I, Muceniece R, Ancans J.: Embryonic stem cell marker expression pattern in human mesenchymal stem cells derived from bone marrow, adipose tissue, heart and dermis. Stem Cell Rev 2009, 5:378-386.

51. Pierantozzi E, Gava B, Manini I, Roviello F, Marotta G, Chiavarelli M, Sorrentino V: Pluripotency regulators in human mesenchymal stem cells: Expression of NANOG but not of OCT-4 and SOX-2. Stem Cells Dev 2011, 20:915-923.

doi:10.1186/1746-6148-10-154

Cite this article as: Dueñas et al:: Hepatogenic and neurogenic differentiation of bone marrow mesenchymal stem cells from abattoirderived bovine fetuses. BMC Veterinary Research 2014 10:154.

\section{Submit your next manuscript to BioMed Central and take full advantage of:}

- Convenient online submission

- Thorough peer review

- No space constraints or color figure charges

- Immediate publication on acceptance

- Inclusion in PubMed, CAS, Scopus and Google Scholar

- Research which is freely available for redistribution

Submit your manuscript at www.biomedcentral.com/submit
() Biomed Central 